\title{
RUDAŠ Jutka
}

Maribori Egyetem, Bölcsészettudományi Kar

Magyar Nyelv és Irodalom Tanszék

Maribor, Szlovénia

jutka.rudas@um.si

\section{A TÖRTÉNELEM TERHE A TÖBBKULTÚRÁJÚSÁGBAN Dragan Velikić poétikájáról}

\section{The Burden of history in multiculturalism}

On the poetry of Dragan Velikić

\author{
Teret istorije u multikulturalnosti \\ O poetici Dragana Velikića
}

\begin{abstract}
Dragan Velikić a történelmi tapasztalatot és a lét kérdéseit egy nyitott, plurális gondolkodás horizontjába helyezi, s kifinomult érzékenységgel, mélyen és sokoldalúan fogalmazza meg a Pulából kiinduló, Belgrádon és Budapesten keresztül húzódó, Bécsig terjedő utazásnak a belső és külső szeletét. E térség történelmének demitologizált részét tárja elénk az egyén és a kollektív emlékezet révén, erös utalásrendszert kiépítve. A kultúra konnektív struktúrájának összefüző hatását Velikić a társadalmi síkon és az idődimenzióban fejti ki, ahol a cselekedetek láncolatai felismerhető mintákba rendeződnek, egy közös kultúra azonosítható mozzanataként. Mindez egy archivált emlék, ahol - Ricoeurrel élve - az emlék ,,mindenkorenyémvalóságát” analogikus átvitel révén az emlék „mindenkor-miénkvalóságává” tágítja. Tanulmányomban azt fogom vizsgálni, mennyire képes megmozgatni Velikić poétikája a szerteágazó kulturális alakzatokat és a társadalmi folyamatokat. Ugyanis regényei olyan fluktuáló időben jelölik a térséget, melyben világosan rámutat a polarizáltság történelmi érzékenységére, éltetve a kulturális tapasztalat heterogenitását.

Kulcsszavak: Dragan Velikić, történelmi narratíva, kulturális emlékezet, mikrotörténet, kollektív identitás
\end{abstract}


Dragan Velikić szerb író a történelmi tapasztalatot és a lét kérdéseit egy nyitott, plurális gondolkodás horizontjába helyezi, s kifinomult érzékenységgel, mélyen és sokoldalúan fogalmazza meg a Pulából kiinduló, Belgrádon és Budapesten keresztül húzódó, Bécsig terjedő utazásnak a belső és külső szeletét. „Nem tudja az ember, mi a rosszabb, a Kelet trehánysága vagy a Nyugat szabályozottsága. Az én igazi elemem: a vasúti kocsi. Legyen az embernek egy kalauza, aki mindig a kellő órában szól, mikor és hol kell leszállni, pár órát eltölteni valahol, és folytatni az utazást" (Velikić 2009, 35). Az útvonalak kijelöltettek, melyeken végig kell haladni. „A vonat régóta a gyóntatószéke, az elhalasztott idő színpada, a lehetőségek tárháza, a mozdulatlan középpont. Mindig a vonaton utazva vetett számot bejárt útjaival. Útból pedig sok van, $\mathrm{s}$ mind átvetül a fülke objektívján" (Velikić 2006, 9) - mondja A Domaszewskydosszié címủ regényének főszereplője, vagy Danilo Kiš nyomán a Dante tér Damjanja: „lehet, hogy a közép-európai író képmása utáni nyomozásom saját gyökereim felkutatásává változik át" (Velikić 2001, 171). Velikić figurái a kelet-közép-dél-európai térség történelmének demitologizált útjain haladnak, ennek részét tárják elénk az egyén és a kollektív emlékezet révén, erős utalásrendszert kiépítve. „Rég véget ért az az utolsó utazás a Jugoszláv Vasutakkal Pulából Belgrádba. De az útirányok megmaradtak. Ez is ugyanaz a földrajz. Csak az igazgatás változott. És vele a zászlók, a himnuszok, az egyenruhák. Meg persze a határok" (Velikić 2018, 166). A történelem általános fogalmainak igazságigény-elképzelését felforgatva olyan narratív epizódokat tár elénk Velikić, olyan mikro- és makrotörténeteknek, egyediségeknek és lokalitásoknak a dramaturgiáját nyújtja, melyek emlékezetként funkcionálnak, s amelyek a térség kultúrájának történetei.

A 2019-ben Vilenica-díjjal kitüntetett író poétikája különös művészi erővel tükrözi a rejtéllyel leplezett, de természetesen vállalt kapcsolódását e térség atmoszférájához, ugyanis e nemzetközi díj pontosan az itt élő térben - azaz a Balti-tenger és az Adria, a Bern és Belgrád között - élő népek emberi és kulturális tapasztalatainak múvészi artikulációit díjazza. Velikić a kultúra konnektív struktúrájának összefüző hatását a társadalmi síkon és az idődimenzióban fejti ki, ahol a cselekedetek láncolatai felismerhető mintákba rendeződnek, egy közös kultúra azonosítható mozzanataként.

Milyen döntően fontosak is voltak annak a világnak a fennmaradásához a láthatatlan pillérek, amelyeken olyan változatos életek bontakoztak ki. Hagyományok, regék, százados tradíciók, magántörténelmek - a szocialista valóságba alámerítve, melynek szertartásai és propagandája tartották egyben azt a világot - burjánoztak a mindennapok felszíne alatt. 
Nemcsak a városomban, hanem szerte az akkori országban, kis családi manufaktúrák gyártanak éjt nappallá téve erényeket és téveszméket (Velikić 2018, 59).

Mindez egy archivált emlék, ahol - Ricoeurrel szólva - az emlék „,mindenkor-enyémvalóságát” analogikus átvitel révén az emlék „,mindenkor-miénkvalóságává" tágítja. Tudniillik regényei így nem egy elzárt tudatfolyam visszajáró kísértetei lesznek, és nem is csupán az objektív térben fellelhető színes felületek, hanem sok szellem oszthatatlan közös része, s visszavonhatatlan közös tapasztalata, mi több, egymástól elválasztott életeket összekötő éteri képződménnyé válnak. A szükebb és tágabb régió és a társadalmi rendszer bénító idegenségérzését, az állandóan újrakezdő létezés affirmációját és anatómiáját próbálja megrajzolni megannyi regényében:

Kicsomagolatlan böröndök közt élek. Fél lábbal a kijáratnál. Állandó keresésében a szilárd pontnak, amelyen megpihenhetnék, feltárnám a hibákat, és azután, ily módon megújulva, elindulhatnék a jó irányba. Mert ez, amit most élek, nem lehet az én életem. Semmi sincs a helyén. A dolgok, az emberek, az események egyszerre több árnyékot vetnek. Milyen körülmények kellettek ahhoz, hogy oda jussak, ahova nem kellett volna? (Velikić 2018, 47).

Velikić újrafeltáró, s láthatóvá képes tenni a láthatóságnak azt a dimenzióját, amiben mindannyian részt veszünk, anélkül, hogy magunktól meglátnánk. Továbbá Dragan Velikić a maga abszolút telítettségében ragadja meg és térképezi fel a régiót, kartográfiai alapossággal a helynek mint élő szervezetnek a felépítését hozza létre. Vagy ahogyan az Asztrahánprém címü regényének egyik elbeszélője mondja: „Nekem az irodalomban a topográfia a legizgalmasabb. Abban van a legjobb poézis" (Velikić 2013, 161). Az utazások architektúrájának, a szállodák történetének és utópiájának a tapasztalás általi egymáshoz illesztése is velikići poiezis. Ezt ragyogóan érzékelteti A nyomolvasó címü, Nin-díjjal is kitüntetett regénye, mely az emlékezés nagy feltárása, s melynek elbeszélője a hatvanas éveiben jár (a szerző alteregója?!), akit épp Budapesten ér anyja halálhíre, s ez elindítja benne a régmúlt események lavináját. Azaz az egyes szám első személyü elbeszélő a gyász közvetlen tapasztalatán és a mélység virtuális tapinthatóságán keresztül egy egész letünt belső és külső világot mutat be:

Erzsébet körúti szállásomon ülök, Budapest központjában, azon a júniusi napon - meghalt az anyám. Hangosan mondom ki: Hotel Lipa. Első lakcímünk Pulában. [...] Vinkovciban kifosztották a vagyonunkat - ez az 
első reakcióm anyám halálára. Belülről az ő hangját visszahallva mondtam ki. Az ablakhoz lépek, nézem az autókat és a sárga villamosokat, ahogy szelik a körutat. A bevált módon próbálom tompítani a fájdalmat. [...] Az ö hangján mondom a mantrát: a Palas Ohridban, a Lipa Pulában, a Slon Ljubljanában, a Neboder Sušakon, a Slavija Opatijában, a Terapija Crikvenicában, a Bonavia Rijekában, a Belvi Splitben, a Grand Szkopjéban, az Evropa Szarajevóban, az Union Belgrádban, az Esplanade Zágrábban, a Vojvodina Újvidéken, az Admiral Vinkovciban... (Velikić 2018, 23).

Az első világháború idején kezdődő történet egy anya életét követi végig gyermekkorától haláláig. A közeli és távoli múlt megidézésébe beletartoznak a felmenők, a főszereplőket körülvevő emberek, városok, országok és korszakok, amelyek észrevétlenül elenyésztek, s benne a szétesett Jugoszlávia. A keretül szolgáló személyes élettörténet, azaz egy mikrovilág gyorsan átbillen a kollektív, azaz a makrovilágba, hogy fölfejtse benne egy egész évszázad szövetének különös darabját. A narratív identitás ,elválaszthatatlan a személyes és a közösségi narratív identitás átalakulásaitól, melynek következtében nemcsak a szövegekről, elbeszélések sorozatáról alkotunk magunknak hosszabb vagy rövidebb időre érvényes képet, hanem magunkat és egy kulturális közösséget is felismerünk bennük és általuk" (Thomka 1998, 44). Velikić mindig a „Személyes” valóságost keresi, ebből indul ki, innen ragadja meg a kontúrokat, a perspektívát, egyáltalán a mű egészét, anélkül, hogy lemondana a közvetlen ábrázolásáról, csupán mintegy korrigálja az őt körülvevő látszatokat. A nyomolvasó feldolgozza, átéli és értelemmé alakítja a fakticitásban megélt élményeket. De persze a spontán percepcióban megélt perspektíva a müben nem mindig azonos a valóság perspektívájával, noha nagyon a valóság körül oszcilláló, de azzal soha nem teljesen egybevágó, s az élet és mü párhuzamos explikációja világosan rámutat arra, hogy egymásba épülő, egymást tükröző alakzatainak az illesztékei. Ez a valóságos határt közelítő spontán áramlás az immaginációba adja a velikići regények dinamikus viszonyát, illetve azt a fikciót, vagyis még inkább az immaginációt, mely nem a szabad szemmel látható való világ sajátja. Ezzel Velikić szövegvilága olyan dimenziót hoz létre, amely a valóságot nem mint előttünk kiterített, teljesen feltárt világot mutatja meg, hanem mint tőlünk visszahúzódó, kifürkészhetetlen, rejtőzködő valóságot, s ezáltal a nála megjelenített látható való világ a szöveg narratív keretébe vibráló erővel s különböző perspektívákkal és kontúrokkal épül bele.

Individuumokat és csoportokat helyez el világuk időbeli változásában, és ebben a dimenzióban bontakoztatja ki a térség társadalmi és történelmi életét. 
Van nagybetüs Történelem. A merényletek, forradalmak, gyilkosságok, összeesküvések, dokumentumok, közlönyök történelme. És van kis kezdőbetűs történelem, a magántörténelem, mely tanúskodik csupán, habár állandó defenzívában van: ez a bútorok, drapériák, kávédarálók, fazekak, útikalauzok, lépcsők, parkok, udvarok, iskolai újságok, könyvek, mozielőadások, fürdőhelyek, szerelmek története (Velikić 2001, 247).

Velikić a kis- és a nagybetüs történelmi/kulturális (ön)reflexió diszkurzusait egyre hangsúlyozottabban építi be szövegeinek szerkezeteibe, így olyan szemléleti változásokat villant fel, amelyek a második világháború után elhallgatottak voltak, s ezáltal színre viszi a valóság és a majdnem-valóság dialógusát. Tényszerüség és fikcionalitás összjátéka kapcsán bontakoztatja ki a múlt tényleges eseményeinek a jelentés-összefüggéseit. Az imagináció lendülete a valós ismerethez képest, a történelmi tény meggyőző ereje a dokumentumokon keresztül, a tapasztalaton és a szükebb családtagok vallomásain válik erőteljesebbé. Művészetének egyik legnagyobb erénye, hogy a szerteágazó kulturális alakzatokat és társadalmi folyamatokat úgy mozgatja, hogy ezek szétfeszítik a társadalom homogén elképzelését. Olyan fluktuáló időben jelöli a térséget, melyben világosan rámutathat a polarizáltság történelmi érzékenységére, éltetve a kulturális tapasztalat heterogenitását, rámutatva a különböző kulturális entitások és teljesen más történelmi végcélok érdekeinek eltérésére és szerteágazó mivoltára.

Velikić szövegalakzatai olyan történelmi áthallásokat közvetítenek, olyan problémával néznek szembe, amelyekre a történelmi könyvek még nem tudnak ilyen plurálisan összpontosítani, mert a második világháború és a legutóbbi balkáni háború eseményei még viszonylag közel állnak hozzánk, és inkább az emlékezet, mintsem az objektív történelem területéhez tartoznak. A többszólamú szövegek - a különböző történelmi oppozíciók és kódok fiktív rekonstrukciói a történelmi és poétikai világ sokszínű viszonyát teremtik meg. A textuálistól a történelmi kérdések felé való elmozdulás az elbeszélők nézőpontjával szorosan a szöveg kontextusának a figyelembevételét eredményezi, amely itt az esztétikai-etikai és poétikai értékek közötti határfelületeken jön létre. A velikići regényvilágot egyfajta társadalmi érzékenység jellemzi, tudniillik a történet-, történelemképzés oksági-logikai tényezőinek a feltárása felé fordul. Szereplöi a narráció szükséges és szükségszerủ alkotóelemei, olvasatunk során mégis az az érzésünk támad, hogy aki beszél a történetben, az nagyon sokszor egyenlő azzal, aki a valóságban él/irr. Dragan Velikićnél ez olyan finoman rafinált játék, amely módosítja az olvasó kapcsolatát a történelemmel. Erre azért van szükség, 
hogy megerősítse a két világ átjárhatóságát, illetve átjárhatatlanságát, vagyis hogy az adott merev történelmi kereteket lazítsa, felforgassa. A sokszoros nézőpontú müvei egy pluralista szemléletű elbeszélés révén mutatják be a történelem bonyolult koordináta-rendszerét. Ezt támasztja alá a regényei elbeszélőinek ábrázolása és nem utolsósorban az idő és a tér kérdése is. Velikić már az első regényében, a Via Pulában, aztán sorban a többiben - A nyomolvasóban, A Bréma-ügyben, a Lakcímben, a Bonaviában, az Asztrahánprémben, de még az Orosz ablakban is - próbál megfesteni egy világot, és a benne végeérhetetlenül burjánzó politikai és egyéb alakzatok belülről fenntartó és müködtető erejének mibenlétét. Szövegeinek posztulátuma az időben hol távoli, hol közeli, de lokalizálható térben fogalmazódik meg, s történeteit egy olyan történelem szakaszába helyezi el, amikor e térség az emberi természet alakíthatóságával, a társadalmi alakulatok szétesésével és újraszervezésével kapcsolatos félelmekkel küszködött. Egy ilyen fiktív világban, ahol összevegyül igaz és hamis, olyan források bukkannak elö, amelyek a legmélyebb történelmi beágyazódásra hívják fel a figyelmet. „Egészen az ötvenes évek közepéig tart az olasz kitelepülés, de a horvátoké is. A türelmetlenebbek a tengeri utat választják vagy gyalog vágnak neki a karszt szikláin át. Magányos fenyőfák és az adriai éjszakák sötétje örzi a lövések nyomán kihunyt szempárok fényét" (Velikić 2013, 24), avagy „,[a]z a művészember, aki az UDBA megbízásából a belgrádi villák zsákmányolt mütárgyainak értékét becsülte fel, úgy találta, különösen értékes festmények” (Velikić 2013, 61), vagy „[n]égy nappal később elhagyják a »Lipa« szállodát, és beköltöznek a »Marija« villa egyik lakásába a Gupčeva utcában" (Velikić 2001, 125). [...] „Nagyon rövid ideig, egy vagy két éven át, hadiárvákat helyeznek el a Vila Marijában. És azután, a múlt század ötvenes éveinek közepén, új lakói érkeznek: a népfelszabadító háború kiérdemesült harcosai. Ebben a kommunista elitben találtuk magunkat mi is apám átvezénylése után, amikor 1953 novemberében egy nap a Duna-parti szolgálatot adriaira cserélte" (Velikić 2018,28), aztán a történelem íve a XX. század 90-es éveinek, az akkori Jugoszlávia a valóságokba és az igazságokba való hitének darabokra esésébe torkollik.

Amikor 1991 októberében szüleim elhagyták Pulát, a pomeri víkendház kulcsát Milićékre bíztuk. Ők maguk ajánlották fel, hogy gondját viselik a háznak és fizetik a számlákat. „Nincs az az erő, amely felülmúlhatná a barátságunkat" - mondogatták búcsúzáskor. Javában tartott Vukovár ostroma. Dúlt a háború Szlavóniában és Likában. A visszatérés Belgrádba, Szkopjén keresztül, teljes két napba telt. Egy évvel később Milićék 
visszaküldték a víkendház kulcsait valakivel, aki átutazott Belgrádba. Rövid levélben tudatták velünk, hogy mostanság veszélyes szerb házról gondoskodni Horvátországban (Velikić 2018, 71).

...1999. március 24. hajnalban elhagytam Belgrádot. Amikor ugyanaznap kora délután, pár órával azelőtt, hogy az első NATO-bombák lehulltak városomra, leszálltam a vonatról Pesten, a Keleti pályaudvaron, beláthatatlan utca tárult elém. A Fiumei út - Rijekai út -, a Kerepesi temető elött haladva (Velikić 2018, 47).

A valóság számbavétele a múltat a jelennel köti össze, s eme textuális forrás a kollektív emlékezetre támaszt nagy igényt. „A nézőpontok ezen pluralitása olyan kettősségnek is megfeleltethető, melyben adva van a múltból tekintett múlt mint egyik lehetséges perspektíva, és egyúttal adva van a jelen távlati (utólagos) nézőpontjából értelmezett múltnak a fogalma" (Gyáni 2016, 55). A történelem terhe, s ebből kiindulva az emberi sorsok különös kanyarulata, az egyedi velikići figurációs stílussal ragyogó poétikai konstrukcióvá válik. A történelmi vagy a valóságtapasztalat időszerkezete pedig azt mutatja, hogy - Lévinas megfogalmazásával élve - olyan valósággal szembesít bennünket, amely „megelőzi és meglepi a lehetségest” (Rüsen 1999, 201).

Velikić regényeinek elbeszélői meglehetősen körülhatárolt időben és térben élve a saját nézőpontjuk szabta korlátok közül nehezen tudnak kimozdulni, szinte áthidalhatatlanok a szemléletbeli és ideológiai különbözőségek, azonban az elbeszélők koordinátái között gyakoriak az átfedések, ismétlődnek vagy újrakezdődnek a tapasztalásokon alapuló cselekvések, emlékek. Ugyanis „,az irodalom és a történelem azzal egy időben, hogy alapvetően másképp müködteti az elbeszélést, a történetmondást, jelentős tapasztalatokat hordoznak egymás számára a létesülés és az értelmezés perspektívájában is" (Thomka 2007, 1373).

Velikić zseniálisan artikulálja azokat a kulturális különbségeket, melyek az idők során e kulturális térben hoztak/hoznak létre új társadalmi és történelmi formációkat. Homi K. Bhabha szavaival élve, artikulálja azt a nézőpontot, mely szerint ,a kulturális különbség diszkurzusának szubjektuma pszichoanalitikus értelemben dialogikus és áttételes”, illetve „a kulturális különbség nem csupán az egymással szemben álló tartalmak vagy a kulturális értékek antagonisztikus tradícióinak egymásnak feszülését reprezentálja" (K. Bhabha 1999, 110). Velikić nagyon látja e világ bársonyosságát, puhaságát vagy épp keménységét. Olyan világot fejez ki, amelyben az oszthatatlan Egészet hordozza, mely már nemcsak utalás a dolgokra, hanem az egységben, telítettségben való megidézésük, ami mindannyiunk számára a valóság ismérve. Tehát a részletekben benne foglaltatik 
az Egész, mert Velikić szövegvilágát sohasem a nagy vonások vonzzák, hanem a mellettük elhelyezett kicsi vonalak, az aprólékos, türelmes nüanszok, kontúrok, és ez az effektus vibráló hatást kelt, hiszen minden belülröl van megvilágítva, $\mathrm{s}$ valami tompa, mélyről jövő fény mindig kívülre sugárzik. Müvészete érzékeli a külső meghatározó dolgokat és eligazodik közöttük, hisz valamelyest figuráinak egész élete ebbe a perceptuális környezetbe ágyazódik, ebbe a minden erejével meghatározható, ugyanakkor meghatározhatatlan értelmű fantazmába.

Bárhova vetődöm el, magamba szívom a hanglejtéseket, gesztusokat, mosolyokat, árnyékokat, a tárgyak elrendezését, szemvillanásokat, illatokat, szavakat. Amikor sok évvel később széthullik a hazám, és lassan elenyészik a középosztály mindama olyannyira tarka világával, az egész korszakot az emlékezetemben elraktározott benyomások alapján fejtem meg. Ezekben a jelzetekben bújtak meg a lényegi tényezők, melyek évtizedeken keresztül lappangtak magukban (Velikić 2018, 58).

Velikić regényeiben nem mindig a körülmények alakítják az életet, hanem az élet hozza létre a körülményeket, mintha a szereplők élete közjátékok és történetek sorozata lenne, mintha minden elöd bennük folytatná félbeszakadt életét. Mindig elég egyetlen részlet, hogy kiderüljön, nem azt az életet élik, amit élni vélnek, ezért sodródnak. Átengedik magukat a mozgás saját ütemének, eltorlaszolva minden változás lehetőségét, s nem szeretve szeretnek, nem cselekedve cselekszenek, ezért mindig a felszín alatt leledzenek, valahol a mélyben; nem tudnak letérni a vágányról, és behatolni az élet jeltelenül maradó repedéseibe: „Létezik a mélység gyönyöre, a legalul lévők gondtalansága a bizonyosság, hogy rosszabb már nem jöhet idelent. A szenvedély örülete és a félreértések esztelensége nem létezik a fenéken. Csak a jámbor önáltatás, az elhessegetett gyanú, hogy esetleg létezik egy még lejjebb lévő, rejtett szint is" (Velikić 2001, 90). Sorsesemény ez? Vagy olyan esemény, ,,amely elsajátíthatatlan idegenséggel szembesít bennünket [...], vagy olyan értelemképződés kezdeteire bukkanhatunk benne, amely éppenséggel mondanivalót kíván nekünk" (Tengelyi 1998, 166)? Dragan Velikić a leglenyügözőbb módon próbál választ keresni e kérdésre is a Bonavia címủ Duna-mediterrán keresztirányú közép-európai regényében, melyben előtérbe lép a fiktív szerző-figura és az önreflexió modern prózapoétikája. Marko Delić bolyongása Budapesten kezdődik, majd visszakanyarodik Belgrádba, elágazódik Bécsbe és Bostonba, majd Rijekában/Fiuméban lel a kezdetekre. „Nincs olyan életmodell, amely a megvalósított valójától függetlenül létezne, olyan modell, amelyet követnie kellett volna, hogy végül célja küszöbére érjen. Vagy élet az élet, vagy vala- 
minek az utánzása, amibe beleveszel. Egy nem létezés másolata. Nonszensz, de mégis..." (Velikić 2014, 43). Avagy A Bréma-ügy XX. századi kelet-középeurópai regényében, melyben a tágabb, Odesszától Brémáig terjedő térségben, Belgráddal és Crikvenicával érintkezve az emlékfolyam középpontjában Ivan Bazarov - a történelem örökös abszolvense, az abszolút hallású és meg nem élt életek végeláthatatlan archívumát birtokló - éjszakai portás apakeresése áll.

Velikić a múlt és jelen komplexitását, a térség történelmi és politikai alakulatainak különféle interpretációját úgy próbálja elénk tárni, vagyis úgy szervezi meg a történeti tapasztalás értelmezését, „,hogy az érintettek az értelmezett tapasztalással saját életgyakorlatukat orientálják az időben, s közben életgyakorlatuk idővonatkozásában kifejezésre és érvényre juttathatják önmagukat" (Rüsen 1999, 42). S mindezt Witold Gombrowicz naplójából kiidézve mondja el A nyomolvasó 9. fejezetében:

Közlekedésünk a múlttal egyenlő a folytonos csiszolgatásával, a megidézésével és felelevenítésével, de mivel az általa hagyott nyomokból olvassuk ki, és azok a nyomok függvényei az esetlegességnek, a közvetítésük anyagának, mely lehet törékeny vagy kevésbé törékeny, különféle eseményeknek, amiket az idő hoz, ez a múlt tehát kaotikus, esetleges, fragmentális... (Velikić 2018, 73).

Velikić végigutazza Közép-Európát, de legmélyebben a jugoszláv mitológiába megy bele, ennek végzetes panteonjába, ahol a különbözőség hangja szólal meg, s mintegy távolságtartó s ugyanakkor benne lévő pozícióból képes bemutatni a körülhatárolható másságot, s ragyogóan képes hasznosítani a kulturális minták eltéréseit. Szövegei végső soron azoknak a kötődéseknek a formáiról és állapotairól szólnak, melyben az ilyen térség lehetővé teszi az ember számára, hogy bizonyos történelmi tapasztalatoknak a gazdagításán keresztül felfedezze saját entitását és világlátását, vagy úgy, hogy megerősíti, vagy úgy, hogy megváltoztatja azt. Velikić interszubjektív tapasztalatainak megidézése, rejtjeles utalásai, stílusának diffúz világossága különös módon megteremti élet és irodalom paradoxonát, s ez világosan látható mindegyik regényében: tömérdek kudarcot és végül a legnagyobb sikert, hiszen valahogy úgy alakultak a könyvei, hogy - akár a legtöbb regényalakjának - talán magának az írói Én-nek is az irodalom lett a világ, és a benne való létezés egyetlen módja, és mindent, amit elmulasztottak, az is része lett az életüknek, mert valahogy mégsem lehet egészen kilépni a saját életünkből, ugyanis nem szembesülhetünk soha színről színre a minket mozgató szabadság abszolút konkrétumával. Ezt igazolják a felhasznált kortörténeti dokumentumok, az intellektuális asszociációk, a fragmentált 
szerkezet, melyek mind-mind átértelmezik az archetípusokat, a szövegidézetek pedig fellazítják a regénystruktúrát. A velikići textusba transzformációk során akarva-akaratlanul egymással/egymásba keverednek különféle szövegek. „Az egymás mellé került idegen szövegek új keretük révén megváltozott funkcióban legyürik (kulturális) idegenségüket (asszimilálódnak), ugyanakkor meg is örzik, ezzel mintegy kifelé mutatnak a szövegből (asszociálódnak)" (Rudaš 2006, 126). Ilyen reflektív szövegek közé sorolhatjuk többek között Andrić, Kavafisz, Kundera, Handke, Kiš, Gombrowicz, Brodszkij, Salieri, Dante, Vergilius, Márai, Petri György, Herman Broch, Borislav Pekić, Musil, Gazdanov és még soksok más szerző szövegtöredékeit is, így a beépülő szövegegységek a kialakult narrációba és diszkurzusba integrálódva egységes esztétikai képet mutatnak. Müveiben az oda-vissza mozgás - a szövegben található szeriális, aleatorikus összjátékokig - a dokumentum és az intertextus átfogó vonatkozási mezejének és a történelem terhének rendelődik alá.

\section{Irodalom}

Gyáni Gábor. 2016. A történelem mint emlék(mü). Budapest: Kalligram.

K. Bhabha, Homi. 1999. DisszemiNáció: A modern nemzet ideje, története és határai. In Narratívák 3: A kultúra narratívái. Szerk. és a szövegeket gondozta Thomka Beáta. Budapest: Kijárat Kiadó.

Rudaš Jutka. 2006. A szellem finom játéka. Budapest: Kijárat Kiadó.

Rüsen, Jörn. 1999. A történelem retorikája. In Narrativák 3: A kultúra narrativái. Szerk. és a szövegeket gondozta Thomka Beáta. Budapest: Kijárat Kiadó.

Tengelyi László. 1998. Élettörténet és sorsesemény. Budapest: Atlantisz.

Thomka Beáta. 1998. Világmetszetek, mikrovilágok, szemcsék. Alföld (2): 42-47, [online] https://epa.oszk.hu/00000/00002/00026/thomka.html (2021. ápr. 20.)

Thomka Beáta. 2007. „Kulturális és kontextuális narratológia”. In Nem süllyed az emberiség. Szerk. Jankovics József. Budapest: MTA Irodalomtudományi Intézet.

Velikić, Dragan. 2001. Dante tér. Ford. Csordás Gábor. Pécs: Jelenkor Kiadó.

Velikić, Dragan. 2006. A Domaszewsky-dosszié. Ford. Bognár Antal. Budapest: Napkút Kiadó.

Velikić, Dragan. 2009. Orosz ablak. Ford. Bognár Antal. Budapest: Geopen Könyvkiadó.

Velikić, Dragan. 2011. A Bréma-ügy. Ford. Bognár Antal. Budapest: Napkút Kiadó.

Velikić, Dragan. 2013. Asztrahánprém. Ford. Bognár Antal. Budapest: Napkút Kiadó.

Velikić, Dragan. 2014. Bonavia. Ford. Bognár Antal. 43. Budapest: Napkút Kiadó.

Velikić, Dragan. 2018. A nyomolvasó. Ford. Bognár Antal. Budapest: Geopen Könyvkiadó. 


\section{THE BURDEN OF HISTORY IN MULTICULTURALISM On the poetry of Dragan Velikić}

Dragan Velikić sets the historic experience and the questions of existence into the horizon of an open, plural thinking, and formulates the internal and external strata of a travel from Pula to Vienna via Budapest and Belgrade with a refined sensitivity and in a versatile way. He unveils to us the de-mythologised history of this region through the remembrance of the individual and the collective, establishing a strong system of reference. Velikić explains the linking impact of the connective structure on a social layer and temporal dimension, where the chains of actions align into recognisable patterns as an identifiable moment of a common culture. All this is an archived memory, where, to quote Ricouer, the "all-time-self-reality" of the memory is expanded by the "all-time-common-reality" through analogical transmission. The study wishes to research the extent to which the poetics of Velikić is able to mobilize the far-reaching cultural forms and social processes. His novels mark the region in a fluctuating era in which he clearly shows the historical sensibility of being polarised, celebrating the heterogeneity of cultural experience.

Keywords: Dragan Velikić, historical narrative, cultural remembrance, micro-history, collective identity

\section{TERET ISTORIJE U MULTIKULTURALNOSTI O poetici Dragana Velikića}

Dragan Velikić istorijsko iskustvo i pitanje opstanka smešta u horizont otvorenog i pluralističkog poimanja, te sa istančanom senzibilnošću, duboko i sveobuhvatno opisuje unutrašnje i spoljašnje segmente putovanja koje kreće od Pule i preko Beograda i Budimpešte stiže do Beča. On demitologizovani deo istorije ovih prostora prikazuje kroz individualno i kolektivno sećanje, stvarajući snažnu mrežu uzajamne povezanosti. Međusobni uticaj konektivne strukture kulture Velikić pronalazi u društvenoj i vremenskoj dimenziji, u kojoj se radnja odvija prema prepoznatljivim obrascima, kao momenti poistovećivanja jedne zajedničke kulture. Sve to predstavlja arhiviranu uspomenu, gde se - po Rikeru - lični doživljaj stvarnosti analogijom proširuje u uspomenu kolektivne stvarnosti. Rad analizira u kojoj meri Velikićeva poetika može da pokrene sveobuhvatne kulturne forme i društvene procese. Naime njegovi romani opisuju ovaj prostor u fluktuiranom vremenu koji jasno ukazuju na istorijsku osetljivost polarizovanosti, oživljavajući heterogenost kulturnog iskustva. Ključne reči: Dragan Velikić, istorijska narativa, kulturno sećanje, kolektivni identitet 